\title{
Los cocodrilos también lloran
}

Keywords: seres sintientes; cocodrilos; Humane Society International; violencia

Las expresiones populares reflejan de forma directa el sentir popular. Con sentido peyorativo se usa en castellano la expresión, "lagrimas de cocodrilo", para caracterizar a quien finge una pena y está a la espera de que sus lágrimas provoquen una reacción favorable en quien le observa, pues parece imposible que un cocodrilo pueda, en realidad, llorar. En las fábulas de Samaniego (1745-1801), el cocodrilo recibe un apelativo de sentido similar, que algunos conservamos en la memoria: "el taimado cocodrilo". Es decir, el gran cocodrilo que observa a su víctima en el río, con expresión atenta y paciente, que le recomienda no beber y andar al mismo tiempo, dispuesto a encontrar el mejor momento para atacarle..., por lo que el perro "prudente" -a decir del autor-, le responde que no es sano beber y andar, pero menos lo es el "seguir del enemigo el consejo" (!).

No pongo en duda que pueda resultar válida la moraleja de la fábula y que la prudencia incluya tomar cautelas, cuando se trata de rozar la "delgada línea roja", que a veces nos sale al encuentro, de forma súbita, cuando tratamos con según quien y según cómo...; pero, hablando de cocodrilos, no podemos evitar contemplarlos como un enemigo potencial, un peligro que nos acecha, por lo que, el lenguaje corriente, les ha reservado ese papel. Por no hacer referencia a las imágenes infantiles -que podemos tener grabadas en la memoria-, del Capitán Garfio en "Peter Pan"[1], atravesando fronteras, huyendo del voraz cocodrilo que se ha tragado su reloj de bolsillo: tic, tac, tic, tac..., como un tambor que le anuncia su cadalso!.

Sin embargo, puede que no sea así y que los cocodrilos (fuera bromas!), también tengan sentimientos, sentido de pertenencia, fuertes lazos familiares y afectos que saben demostrar. Algo que la ciencia ha demostrado y que, a través de las investigaciones de Vladimir Dinets (http://dinets.info/), presentadas en un reciente congreso, celebrado en Washington D.C., organizado por la Humane Society Internacional, se ha ofrecido como resultado fiable[2]. Puede que tengamos que replantearnos, como en tantas cosas, cúal es nuestra relación con los animales, desprovistos de prejuicios, aunque no necesariamente haya que empezar por los cocodrilos!.

Está por hacer una revisión del lenguaje en relación con los animales, que refleje lo que la ciencia, que los califica como "seres sensibles", ha alcanzado como evidencia. La sentiencia animal, debería impregnar nuestra mentalidad, como un valor adquirido, un valor ciudadano que nos sirva para rehacer las relaciones que el Derecho utiliza para regular nuestra sociedad que, necesariamente, incluye a los animales y no en situación de subordinación al ser humano[3].

Que compartimos un elevadísimo tanto por ciento con los simios, está hoy fuera de toda duda. No obstante, hay quien tira plátanos al punto de corner en los estadios de futbol, con intención de ofender a un jugador de color. Por no hablar del grito coreado por el público, que quiere imitar los sonidos de estos animales en la selva, con el mismo sentido ofensivo, violento y ridiculizante. En realidad, estamos hablando de nuestros "primos hermanos", así que, en cuanto acabe de escribir, me voy a comer un plátano y, a lo mejor, hasta me dedico un "selfie" y lo cuelgo en las redes sociales. 
[1] BARRIE, J.M., Peter Pan, or the boy who wouldn't grow up (London 1904)

[2] GIMÉNEZ-CANDELA, T., Seres sintientes

[3] Vid. las conclusiones del Congreso sobre Sentiencia Animal y Estrategias de aplicación 